\title{
Representation of Local Cultures and Female Masculine in the Television Show "Berburu"
}

\author{
Tantri Puspita Yazid \\ Faculty of Social and Political Science \\ Universitas Riau \\ Riau, Indonesia \\ tantri.yazid@lecturer.unri.ac.id
}

\author{
Fitri Hardianti \\ Faculty of Communication \\ Universitas Padjadjaran \\ Bandung, Indonesia \\ fitri.hardianti94@gmail.com
}

\begin{abstract}
Hunting in some areas of Indonesia is a tradition. A tradition that later Became a hobby for hunters who usually joined in a community. Animals are usually hunted wild boar dalah, Because it is considered as a pest for the garden of citizens. even in West Sumatra pig hunting activity is a tardisi that has lasted from the time to amsa and taught from generation to generation. This phenomenon is lifted to the television screen by Trans TV through the Hunting program. As a commercial show, hunting programs use women as an anchor. Women in the media are usually attached with the feminine nature associated with closed, affective, and irrational. Meanwhile, men in the media showed otherwise attached to masculine traits associated with open nature, aggressive and irrational. But today he deconstructed the women in the mass media beginning to display a masculine figure. Similarly, it is interesting to see the nature of masculinity that is attached to women as the bearers of a hunting of wild boar hunting program episodes in West Sumatra. This research uses Rholand Barthes Semiotics analysis, to see signs, signs and myths through the symbols that are displayed in the hunting episode of wild boar hunting in West Sumatra. This research is a qualitative research that puts into perspective from the analysis Described descriptively. The results of the presentation of women masculinity which states that women representation and masculinity are displayed in various ways. The most prominent is the masculine representation in the category of ability to perform heavy-duty trucks in the program) such as holding weapons, night hunting, working with men) and a way of dressing a neat but still highlight the sexiness side by dressing up. Local cultural values are raised in one hunting program by involving local communities and reviews of habits or traditions of hunting wild boar in West Sumatra. It was also illustrated through the music of the Minang area that Became backsound and conversations recorded between local hunters with local languages.
\end{abstract}

Keywords-local culture; mass media; female masculine; semiotics; television

\section{INTRODUCTION}

Hunting is a tradition practiced by people in Indonesia. Even by the Minangkabau, West Sumatra, this tradition has continued until now. This tradition has been preserved from one generation to his following. Hunt conducted by the Minang people are still fairly traditional, and even referred to as the game of the people, the Pig Hunting. Hunting by using dogs. One person used to take 2-3 dogs for hunting locations which have been determined by a group. Hog hunting wild boar hunting is an activity of a group of people with dogs. Usually this hog hunting activity are men, but there are no restrictions for women.

At first, the tradition of hunting pigs in the premises which aims to help farmers repel wild boar that is considered as pests that interfere with agricultural and plantation residents. tresebut last activity on the legitimacy of the government. Legality boar hunting refers to Regulation no 13 of $1994^{1}$, Article 8 states in situations of population explosion protected wild animals to become pests, carried out control measures through hunting. In chapter 3 of Government Regulation No. 13 of 1994 mentioned that the game species is basically protected wild animals. Based on the regulation of the Minister of Forestry Republic of Indonesia P.19 / Menhut-II / 2010, boars are protected wild animals and can be used as a quarry. With the capture of wild pigs, people expect results obtained more abundant harvest. Although initially only to keep yields, recent hog hunting activities gradually actually made a hobby by a group. Even Jim yelled, an artist from Central Java, popular thanks to its masterpiece paintings named "Indonesia in 1998, hunting wild boar"2, The painting is on display in the exhibition of paintings in Jogjakarta in 1999 and was sold for 1 billion rupah time ${ }^{3}$, In southern Sulawesi, wild boar hunting tradition called Maddengeng, done before planting seeds in a field and before the harvest season. In this tradition, the entire villagers take each task, both women and men ${ }^{4}$, In West Sumatra, this habit is called 'baburu kandiak "5

According Koentjaraningrat, hunting is one of the most important livelihood in almost all food gatherer tribes in the world. Habits are continually made and passed down to the next generation then become culture in the area. Culture is formed by individuals and are always passed down from generation to generation or transmitted from individual to

${ }^{1}$ Source: paper pig hunting.

http://www.academia.edu/5886406/Makalah_perburuan_babi, accessed on May 16, 2017.

${ }^{2}$ Celeng $=$ pig

${ }^{3}$ Source: Art Insight edition of Metro TV Joko yell: Artists tig agenerasi. (08.06.2017, 14:30)

${ }^{4}$ Source: http://giewahyudi.com/tradisi-berburu-babi-hutan-di-seluruhindonesia/ accessed on August 6th, 2017 at 17:00 pm.

${ }^{5}$ Kandiak: boar 
another in a given society. In the establishment and inheritance, is done through communication, which are represented by symbols commonly understood, namely language. So, I wonder if said culture is formed by the communication through language or cultural form of communication through language. This phenomenon is captured into the display glass and communicated by audio and visual via the program Hunting.

In November 2016 episode, in lifting hunting activities by community groups in Solok, West Sumatra. Host for this program consists of one men and one woman. The emcee of women in this program actively participates in hunting activities done by the majority of men. Cultural activities through the symbolic meaning of communication hunter hunting pig in Solok served through programs Berburu and presence of host of programs that tend to be geared to men to be important in understanding and explaining a phenomenon. How is the language used, the presence of female emcee, symbols of hunting culture and the culture of social life in Minangkabau, West Sumatra shown in the episode Baburu Pigs in Solok becomes interesting things.

\section{CONCEPT}

In discourse analysis, there are three views on language. First, the language of the posistivisme-empirical paradigm is considered as a bridge between people and objects outside itself. Human experience considered is expressed directly through the use of language without any constraints or distortion as far as the statement is logical, syntactic, and have a relationship with a real experience. Second, the language in the paradigm of the kosntruktivis deemed to contain specific intent of the subject. Third, in view of the critical language is not considered a neutral medium but always engaged in relations of power and representation in community action. Fairclough and Wodak argued that critical discourse analysis to investigate how through language, social groups fight each other and asking each version [1].

Foucault in Mills [2, p. 57] argues that language is not just a means of forcing people to believe in the ideas that are incorrect or not in accordance with their interests, language is also a place of struggle. Foucault states:

"As history has always taught us that discourse (discourse) is not just something that translates struggles or systems of domination; discourse is something there for the cause. "

Foucault in Mills [2, p.56] also stated that the opposition was contained in the idea of the power; 'Where there is power, there is also resistance.' For Foucault, there is no relation of power which is the total domination. As a consequence, there will always be a challenging force or tear it down.

\section{METHOD}

This research is a qualitative research. Kirk and Miller in Moleong [3, pp. 4-6] says that qualitative research is a certain tradition in social science that is fundamentally dependent on the observations in humans, both in the region and in their terminologies. Moleong also explained that the study was based on an attempt to establish their views are examined in detail, formed by the words, holistic and complex. Jane Richie in defining Moleong qualitative research in an attempt to present the social world and its perspectives in the world in terms of concept, behavior, perceptions and issues about man being investigated.

Based on the issues to be discussed and the framework used in this study, the research paradigm is critical paradigm. Epistemological, critical paradigm considers that its relations with the studied investigators always bridged certain values. An understanding of reality isvalue mediated findings, Ontologically, observable reality is the reality of 'pseudo' which has been formed by the processes of historical and social forces, cultural and political economy. While the Axiological, researchers looked at the critical paradigm as an activist. As for values, ethics and moral choice is an integral part of the research. Researchers put myself as a transformative intellectual, advocates and activists. The research objective is to undertake social criticism, transformation, social emancipation and empowerment.

This study uses a model of critical discourse analysis which assumes Sara Mills text as a meeting place for writers and readers. Moreover, the notion Mills also focuses on the positions of the actors displayed text; party who is the subject and object of storytelling that will determine the treatment of the text structure and meaning of the text as a whole. In the end how storytelling and positions that are placed and displayed in text made into a legitimate one party and the other party illegatimate. Therefore this analysis was not focused on the elements of language [1, p. 200].

By using critical discourse analysis Sara Mills; subjectobject position and the position of the reader at the level of the text and the context that gave birth to the text, the researchers will look at how a cultural symbol and women in the event program hunting boar hunting episode in Solok, West Sumatra with a critical approach.

\section{RESULT AND DISCUSSIONS}

The author presents the results of the analysis carried out on impressions episode hunting boar hunting program in Solok, West Sumatra. Based on the analysis used a knife, the analysis is done on two dimensions: the dimension text or dimensions of the micro and macro dimensions of context or dimension. Analysis of macro dimensions is done by tracing the history of the tradition of hunting pigs in West Sumatra and debate as well as its relation with the position of women in the prevailing custom that has continued until today. While the analysis of the dimensions of the micro do with menggambarakan scenes, symbols of the tradition of hunting clothing in Solok, West Sumatra and the position of women on impressions based analysis framework Sara Mills.

At the macro level or social ehidupan past and present, hunting, including hunting pigs in Minangkabau society is a form of folk games that have become a tradition. However, the authors have not found literature that records exactly when 
this activity began to be played by the community, but as a form of traditional folk games in the adage mentioned that; "Baburu pig suntiang niniak mamak, pamenan deck nan mudo in villages" (boar hunting is a proud community leaders and games for the youth). Bbai hunting activities undertaken by men in Minangkabaus ecara groups. Zainal Arifin, in his study stated [4], Hunting Pigs are male identity politics Minangkabau ${ }^{6}$, It is based on the indigenous culture that prioritizes women Minangakabau called matrilineal. More Arifin explained that the pig hunt bsia be regarded as a form of resistance men in Minangkabau especially urang Sumando ${ }^{7}$, Hog hunting activity in any place in West Sumatra, nobody followed by women.

At first, boar hunting community Minangkabau institutionalized, they are in control of the Penghulu and Ninik-Mamak traditional leaders, each and every Jorong usually contained a "Mucak Buru", and in each surroundings appointed someone who is called by "Kapalo Mudo", according to Minangkabau adat they were called; "Gadangnyo batampek, tingginyo dapaek dijuluak, batampek tried adaik, duduak manghadok ka panghulu ", or they referred to as the proverbial Minangkabau society as "mato manantang field", ie those who carry out the field work of government activity. The appointment of a person to be muncak rush and Kapalo mudo, usually followed by a thanksgiving ceremony, a minimum by slaughtering a goat, while the rice was taken by the people and the surroundings in which the ellipse leadership election was conducted. Mucak Buru and Kapalo Mudo, at the hunting ground is the person most responsible for everything that happens in the area of the hunt, all participants of the hunt must submit to the command and the command given by Muncak Buru and Kapalo Mudo, while Ninik-Mamak and Penghulu received reports regarding hunting activity. But today, hunting activities seem to be a showcase of male masculinity in Minangkabau. Become a hobby or pleasure that should continue to be channeled into hunting groups called Pork Hunting Association (PORBI) or through PERBAKIN for weapon-hunting activities. Boar hunting is no longer intended simply to help repel pests' boar. Hog hunting activity is currently a form of resistance men in Minangakbau will prioritize indigenous women's position, matrilineal. It can be seen from the absence of women involved in hunting procession. However, different things presented in one of the display in Trans TV episode Hunting boar hunting in Solok, West Sumatra. Where in the program involves a host of women in hunting activities. Emcee women not only bring the show from a distance, but also participate in hunting activities carried out by the pig hunters in Solok. It can be seen from scenes or text that is displayed in the event program. Hog hunting activity is currently a form of resistance men in Minangakbau will prioritize indigenous women's position, matrilineal. It can be seen from the absence of women involved in hunting procession. However, different things presented in one of the display in Trans TV episode Hunting

\footnotetext{
${ }^{6}$ Source: Zainal Arifin in Gadjah Mada University Humanities Journals

Volume 24, Number 1 February 2012. Pages 29-36.

7 The term for a married person husband minang
}

boar hunting in Solok, West Sumatra. Where in the program involves a host of women in hunting activities. Emcee women not only bring the show from a distance, but also participate in hunting activities carried out by the pig hunters in Solok. It can be seen from scenes or text that is displayed in the event program. Hog hunting activity is currently a form of resistance men in Minangakbau will prioritize indigenous women's position, matrilineal. It can be seen from the absence of women involved in hunting procession. However, different things presented in one of the display in Trans TV episode Hunting boar hunting in Solok, West Sumatra. Where in the program involves a host of women in hunting activities. Emcee women not only bring the show from a distance, but also participate in hunting activities carried out by the pig hunters in Solok. It can be seen from scenes or text that is displayed in the event program. It can be seen from the absence of women involved in hunting procession. However, different things presented in one of the display in Trans TV episode Hunting boar hunting in Solok, West Sumatra. Where in the program involves a host of women in hunting activities. Emcee women not only bring the show from a distance, but also participate in hunting activities carried out by the pig hunters in Solok. It can be seen from scenes or text that is displayed in the event program. It can be seen from the absence of women involved in hunting procession. However, different things presented in one of the display in Trans TV episode Hunting boar hunting in Solok, West Sumatra. Where in the program involves a host of women in hunting activities. Emcee women not only bring the show from a distance, but also participate in hunting activities carried out by the pig hunters in Solok. It can be seen from scenes or text that is displayed in the event program. Emcee women not only bring the show from a distance, but also participate in hunting activities carried out by the pig hunters in Solok. It can be seen from scenes or text that is displayed in the event program. Emcee women not only bring the show from a distance, but also participate in hunting activities carried out by the pig hunters in Solok. It can be seen from scenes or text that is displayed in the event program.

Women in the program emcee Hunting impressions placed on posiis sunjek. Wherein, the main character who dominates sustainability impressions event. In addition, the carrier means women are also required to be masculine and can follow hunting, not only as a display. It can be seen from scenes where women ACRA carrier at night took hold of weapons, hunting and ran with men chasing her hunting results. Female symbol of a strong, virile and mighty in the show in this program. However, as a commercial products, the appearance of the carrier remained in tampailkan aperempuan ACRA in section through used clothing complete with flashy makeup.

Representation of local culture and women masculine in the program display hunt in tRNAs TV episode Hunting wild boar in Solok, West Sumatra lifted a phenomenon crocodile that has been going on for generations, which is part of a hobby or pleasure men in Minangkabau which show the existence of self-identity on customary matrilineal dominance. However, in these program, the woman who hosted in are 
allowed to participate in hunting activities to show power of women over men. Unfortunately, women at present on the market demand is not power over themselves because they symbolized as something "behavior if sold" through the attributes used to be something not suitable for wild boar hunting attributes at night in an area.

\section{REFERENCES}

[1] Eriyanto, Analisis Wacana [Discourse Analysis]. Yogyakarta: LkiS, 2006.

[2] S. Mills, Diskursus, Sebuah Piranti Analsis dalam Kajian Ilmu Sosial [Discourse, A Analytical Device in Social Science Studies]. Jakarta: Qalam, 2007.

[3] L. J. Moleong, Metode Penelitian Kualitatif [Qualitative Research Method]. Bandung: Remaja Rosdakarya, 2006.

[4] Z. Arifin, "Buru Babi: Politik Identitas Laki-Laki Minangkabau [Buru Babi: Minangkabau Male’s Political Identity]," Jurn. Human., vol. 24, no. 1, pp. 29-36, February 2012. [Online]. Available: https://journal.ugm.ac.id/jurnal-humaniora/article/view/1037/866. [Accessed Aug. 3, 2017]. 